\title{
PENGARUH KARAKTER RASA INGIN TAHU SISWA TERHADAP HASIL BELAJAR MATA PELAJARAN IPA FISIKA DI SMP NEGERI 08 MUARO JAMBI
}

\author{
Siska Novelyya \\ Progam Studi Pendidikan Fisika, Universitas Jambi \\ Email: Novelyya05@gmail.com
}

\begin{tabular}{l}
\hline Tersedia Online di \\
http://www.jurnal.unublitar.ac.id/ \\
index.php/briliant
\end{tabular}

Sejarah Artikel

Diterima pada 22 April 2019

Disetuji pada 2 Mei 2019

Dipublikasikan pada 22 Mei 2019

Hal. 174-181

\begin{tabular}{l}
\hline Kata Kunci: \\
Rasa Ingin Tahu, Siswa, Fisika
\end{tabular}

DOI:

http://dx.doi.org/10.28926/briliant .$v 3 \mathrm{i} 4.291$

\begin{abstract}
Abstrak: Penelitian ini bertujuan untuk mengetahui apakah karakter rasa ingin tahu siswa memiliki pengaruh terhadap hasil belajar mata pelajaran IPA Fisika di SMP Negeri 08 Muaro Jambi. Jenis penelitian ini adalah Deskriptif Statistik, yaitu menggunakan lembar angket berisi indikator-indikator. Populasi penelitian meliputi kelas VII, VIII, dan IX SMPN 08 Muaro Jambi, dengan jumlah keseluruhan 497 siswa. Sampel untuk penelitian menggunakan kelas VIII A dan VIII B, dengan jumlah keseluruhan 58 siswa. Teknik pengumpulan data penelitian dengan membagikan lembar angket berisi indikator kepada tiap siswa, yang disertai tanggapantanggapan yang harus dipilih siswa. Data hasil penelitian yang diperoleh menyatakan bahwa, sikap rasa ingin tahu siswa terhadap mata pelajaran IPA Fisika memiliki pengaruh terhadap baik tidaknya hasil belajar siswa tersebut, namun hal tersebut tidak serta merta menentukan hasil belajar mereka. Supaya sikap rasa ingin tahu siswa lebih tinggi dan mendalam terhadap mata pelajaran IPA Fisika, maka pendidik tentunya dapat melakukan sebuah
\end{abstract} metode pembelajaran yang lebih menarik perhatian siswa. Sehingga siswa akan lebih fokus dalam memperhatikan pelajaran yang disampaikan pendidik saat proses pembelajaran berlangsung.

\section{PENDAHULUAN}

Pendidikan berada di kedudukan yang sangat penting dalam kehidupan karena pendidikan berperan sebagai jembatan untuk memperoleh ilmu pengetahuan maupun wawasan yang akan membuat SDM (Sumber Daya Manusia) menjadi sumber daya yang bermutu dan berkualitas. Menurut Wood (2011) dalam Astalini, dkk. (2019), pendidikan diartikan suatu proses mendapatkan dan menanamkan keterampilan yang dilakukan, oleh peserta didik. Menurut Djamarah (2013), efektifitas pendidikan dalam hal membangkitkan ataupun meningkatkan minat belajar siswa agar memiliki keterampilan, yaitu dengan cara melalui minat - minat siswa yang telah ada sebelumnya dan membentuk minat-minat yang baru pada diri siswa tersebut. Hal yang seperti itu diraih dengan upaya membagikan informasi atau pengetahuan pada siswa tentang hubungan antara materi pelajaran yang akan diberikan dengan materi pelajaran yang sebelumnya.

Dalam dunia pendidikan yang sekarang, yaitu kurikulum 2013 revisi, maka dari itu peserta didik diharapkan bersikap ilmiah dalam proses pembelajaran. Kegiatan pembelajaran itu sendiri diselenggarakan bertujuan untuk membentuk watak maupun karakter, membangun pengetahuan, sikap dan kebiasaan-kebiasaan untuk meningkatkan mutu kehidupan peserta didik. Karakter

174 BRILIANT: Jurnal Riset dan Konseptual Volume 4 Nomor 2, Mei 2019 
ataupun watak adalah cara berpikir dan berperilaku yang menjadi ciri khas tiap individu untuk hidup dan bekerjasama, baik dalam lingkup keluarga, masyarakat, bangsa dan negara (Suradi., 2017).

Menurut Erhansyah (2018), tercapainya suatu tujuan dari kegiatan pembelajaran tersebut dikarenakan banyak indikator yang mendominasi serta saling mempengaruhi satu sama lain. Siswa berperan menjadi komponen yang sangat penting untuk diteliti baik itu berupa pengaruh yang datang dari dalam dirinya sendiri maupun bersumber dari lingkungan luar dirinya. Minat ataupun bakat pastinya dimiliki oleh masing - masing siswa yang ikut andil dalam proses pembelajaran. Namun, ketertarikan siswa tersebut harus didorong oleh faktor proses pembelajaran yang dijalani.

Menurut Kurniawan, dkk. (2018), sepatutnya seorang siswa harus memiliki sikap yang baik terhadap mata pelajaran yang mereka pelajari. Sebab, sikap yang baik terhadap pelajaran berpengaruh besar terhadap keberhasilan pencapaian tujuan pembelajaran. Menurut Brigg dalam Erhansyah (2018), hasil belajar adalah seluruh kecakapan dan hasil yang nantinya akan diraih yakni melalui suatu proses pembelajaran di lembaga pendidikan dan ditetapkan dengan angka-angka yang diukur berdasarkan test hasil belajar. Hasil belajar adalah sebuah tujuan yang dicapai setelah mengalami pengalaman dalam kegiatan pembelajaran, sehingga prinsip-prinsip dari Taksonomi Bloom sangat bermanfaat dalam merancang berbagai tingkat tujuan pembelajaran.

Sikap atau perilaku menurut Cavendish dalam Fatonah, dan Prasetyo (2014), menjabarkan bahwa perilaku yang diadaptasi dan diterapkan pada situasi khusus, dapat berbentuk minat/perhatian, apresiasi, suka, tidak suka, opini, nilainilai, dan ide-ide dari seseorang. Sikap kepada mata pelajaran fisika diklasifikasikan menjadi dua, yaitu sikap baik/positif dan sikap tidak baik/ negatif. Dalam mewujudkan siswa yang bersikap ilmiah, dapat didukung dengan mata pelajaran IPA (Astalini, dkk, 2018). Salah satu cabang dari IPA adala fisika. Menurut Heron, P dan Meltzer, D. (2005) dalam Ajeng, dkk (2019), tujuan utama pembelajaran fisika adalah menghasilkan pemecah masalah yang dapat diterapkan dalam dunia nyata .

Kesenangan siswa saat proses belajar IPA bisa diamati dari cara siswa menanggapi pembelajaran tersebut, secara umum indikator kesenangan diwujudkan berupa ekspresi senang ataupun tidak senang dan suka ataupun tidak suka. Sikap-sikap tersebut dari setiap siswa akan menyimpulkan bentuk kesenangan siswa terhadap IPA itu sendiri, sedangkan sikap tidak senang atau tidak suka akan menyimpulkan siswa memiliki rasa tidak senang terhadap IPA. Sikap senang siswa diperlihatkan dengan sikap siswa yang terbuka dan semangat terhadap mata pelajaran IPA di dalam atau pun luar kelas (Kurniawan, dkk: 2018)

Penelitian ini relevan dengan penelitian yang telah dilakukan sebelumnya oleh Lilanamami Arya Yuritantri yang berjudul "Pembelajaran dengan Metode Guided Inquiry Untuk Mengembangkan Rasa Ingin Tahu dan Keterampilan Komunikasi Siswa" yang dilakukan tanggal 9-17 Mei 2013 di MTs Negeri Sulang Kabupaten Rembang, dengan hasil bahwa rasa ingin tahu dan keterampilan komunikasi siswa sebelum dan sesudah dilakukan pembelajaran dengan metode guided inquiry mengalami perbedaan. Oleh karena itu, perlunya penelitian ini dilakukan. 


\section{METODE}

Penelitian ini dilakukan di SMP Negeri 08 Muaro Jambi dengan populasi penelitian meliputi kelas VII, VIII, dan IX yang berjumlah 497 siswa. Sampel untuk penelitian menggunakan kelas VIII A dan VIII B, dengan jumlah keseluruhan 58 siswa. Teknik analisis yang digunakan yaitu Statistic Descriptive. Data hasil penelitian yang dianalisis berupa ketuntasan belajar individu dan ketuntasan belajar secara klasikal (Nurhayati, 2018).

Menurut Agung (2000) dalam Agung (2000), langkah awal untuk analisis statistic deskriptif yakni melakukan analisis data, yang bertujuan mempelajari perbedaan antara fakta yang diobservasi dengan apa yang diharapkan. Pada tahap pertama analisis data merupakan aktivitas ilmiah untuk melakukan penilaian terhadap nilai/ skor/ ukuran variabel atau indikator yang ditinjau, terutama variabel tak bebas atau variabel tujuan atau indikator masalah yang ditinjau. Hasil analisis ini nantinya bisa digunakan dalam menentukan ada atau tidaknya permasalahan. Sebagaimana telah diketahui bahwa suatu permasalahan terjadi atau muncul apabila fakta yang diobservasi tidak sesuai dengan apa yang diharapkan.

Untuk pengambilan data dengan jenis Deskriptif, yaitu pengambilan data kualitatif digunakan isntrumen berupa lembar angket yang diberikan kepada siswa/i di sekolah. Lembar angket yang digunakan diadopsi dari skripsi oleh Lilanamami Arya Yuritantri dari Universitas Negeri Malang yang berjudul “ Pembelajaran dengan Metode Guided Inquiry Untuk Mengembangkan Rasa Ingin Tahu dan Keterampilan Komunikasi Siswa " yang dilakukan tanggal 9-17 Mei 2013 di MTs Negeri Sulang Kabupaten Rembang.

Skala angket yang digunakan dalam penelitian yaitu, skala 1 hingga 4 . Dengan keterangan skala 1 untuk Sangat Tidak Setuju (STS), 2 untuk Tidak Setuju (TS), 3 untuk Setuju (S), dan 4 untuk Sangat Setuju (SS). Jumlah butir pernyataan atau indikator yang digunakan dalam lembar angket tersebut adalah sebanyak 25 butir indikator. Dengan indikator lembar angket tentang karakter rasa ingin tahu siswa yang juga dikaitkan dengan mata pelajaran Ilmu Pengetahuan Alam, khususnya Fisika.

Penelitian ini dilakukan terhadap siswa/i di SMP Negeri 08 Muaro Jambi, yang jumlah poupulasi siswanya dari kelas VII hingga kelas IX sebanyak 497 orang. Dengan jumlah sampel siswa yang dilakukan penelitian yaitu sejumlah 58 orang, dimana kelas VIII A sebanyak 29 orang, dan kelas VIII B sebanyak 29 orang.

\section{HASIL}

Dalam menganalisis data hasil penelitian menggunakan program SPSS. Untuk pengambilan datanya dengan membagikan atau menyebarkan angket pada siswa/i di SMPN 08 Muaro Jambi. Terdapat 25 butir pernyataan sikap pada lembar angket, yang keseluruhan pernyataan merupakan pernyataan positif.

Tabel 1. Contoh bentuk pernyataan sikap rasa ingin tahu

\begin{tabular}{|c|c|c|c|c|c|}
\hline \multirow{2}{*}{ No. } & \multirow{2}{*}{ Pernyataan sikap } & \multicolumn{4}{|c|}{ Tanggapan } \\
\hline & & STS & TS & $\mathbf{S}$ & SS \\
\hline 1. & $\begin{array}{l}\text { Materi fisika sangat menarik perhatian dan } \\
\text { rasa ingin tahu karena banyak berkaitan }\end{array}$ & & & & \\
\hline
\end{tabular}

176 BRILIANT: Jurnal Riset dan Konseptual

Volume 4 Nomor 2, Mei 2019 


\begin{tabular}{|c|l|l|l|}
\hline & dengan alam. & & \\
\hline 2. & $\begin{array}{l}\text { Saya mencatat semua konsep materi fisika } \\
\text { yang dijelaskan oleh guru. }\end{array}$ & & \\
\hline 3. & $\begin{array}{l}\text { Mencari artikel di internet dapat menambah } \\
\text { informasi mengenai materi pelajaran di } \\
\text { sekolah. }\end{array}$ & & \\
\hline 4. & $\begin{array}{l}\text { Pada saat diskusi saya langsung } \\
\text { mengajukan pertanyaan ketika ada } \\
\text { kesempatan bertanya. }\end{array}$ & & \\
\hline 5. & $\begin{array}{l}\text { Saya selalu menanggapi pendapat teman } \\
\text { yang saya rasa kurang tepat. }\end{array}$ & & \\
\hline 6. & $\begin{array}{l}\text { Saya selalu ingin mencari informasi } \\
\text { bagaimana konsep fisika diterapkan pada } \\
\text { kehidupan nyata. }\end{array}$ & & \\
\hline
\end{tabular}

Untuk skala sikap siswa yang digunakan adalah skala Likert. Dengan jenis skalanya Sangat Tidak Setuju (STS), Tidak Setuju (TS), Setuju (S), dan Sangat Setuju (SS). Setiap item skala dalam lembar angket memiliki skor atau nilai: STS $=1$, $\mathrm{TS}=2, \mathrm{~S}=3$, dan $\mathrm{SS}=4$. Didapatkan data dari penelitian yang dilakukan terhadap siswa/i SMP Negeri 08 Muaro Jambi kelas VIII A dan VIII B.

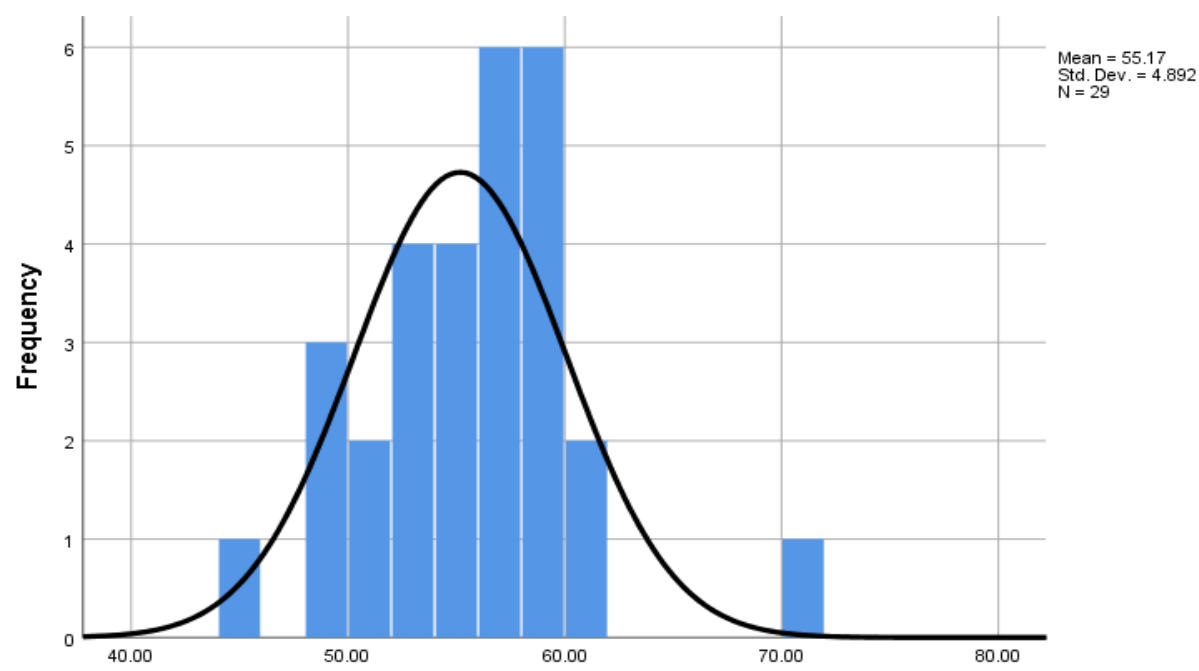

Gambar grafik data kelas VIII A

Untuk data observasi pada kelas VIII A, dengan menggunakan metode deskriptif statistik, data yang telah diperoleh kemudian diolah menggunakan SPSS untuk mendapatkan nilai rata-rata, median, modus, standar deviasi, nilai minimum dan maksimum. Diperoleh nilai terendah yaitu 45 dan tertinggi 70 dari total siswa 29 orang. Untuk nilai rata-rata sebesar 55.17, nilai tengah (median) sebesar 56, nilai yang paling banyak diperoleh yakni 53, dan untuk standar deviasi atau tingkat keragaman data sebesar 4.89.

Untuk total nilai itu sendiri yaitu 100 dan jumlah siswa keseluruhan dalam presentase yakni $100 \%$. Dari data nilai yang diperoleh siswa di kelas VIII A, diantaranya nilai 45 diperoleh oleh 1 siswa dengan presentase $3.4 \%$, nilai 48 diperoleh oleh 2 siswa dengan presentase $6.9 \%$, nilai 49 diperoleh oleh 1 siswa 
dengan presentase $3.4 \%$, nilai 50 diperoleh oleh 1 siswa dengan presentase $3.4 \%$, nilai 45 diperoleh oleh 1 siswa dengan presentase $3.4 \%$, nilai 51 diperoleh oleh 1 siswa dengan presentase $3.4 \%$, nilai 53 diperoleh oleh 4 siswa dengan presentase $13.8 \%$, nilai 54 diperoleh oleh 4 siswa dengan presentase $13.8 \%$, nilai 56 diperoleh oleh 3 siswa dengan presentase $10.3 \%$, nilai 57 diperoleh oleh 3 siswa dengan presentase $10.3 \%$, nilai 58 diperoleh oleh 3 siswa dengan presentase 10.3 $\%$, nilai 59 diperoleh oleh 3 siswa dengan presentase $10.3 \%$, nilai 60 diperoleh oleh 1 siswa dengan presentase $3.4 \%$, nilai 61 diperoleh oleh 1 siswa dengan presentase $3.4 \%$, dan nilai 70 diperoleh oleh 1 siswa dengan presentase $3.4 \%$.

Untuk rentang klasifikasi lembar angket " Karakter Rasa Ingin Tahu ", siswa pada kelas VIII A SMP Negeri 08 Muaro Jambi, sebagai berikut:

1. Rentang $25-43,75$ dalam kategori sangat tidak baik

2. Rentang 43,76-62,5 dalam kategori tidak baik

3. Rentang $62,6-81,25$ dalam kategori baik

4. Rentang 81,26 - 100 dalam kategori sangat baik

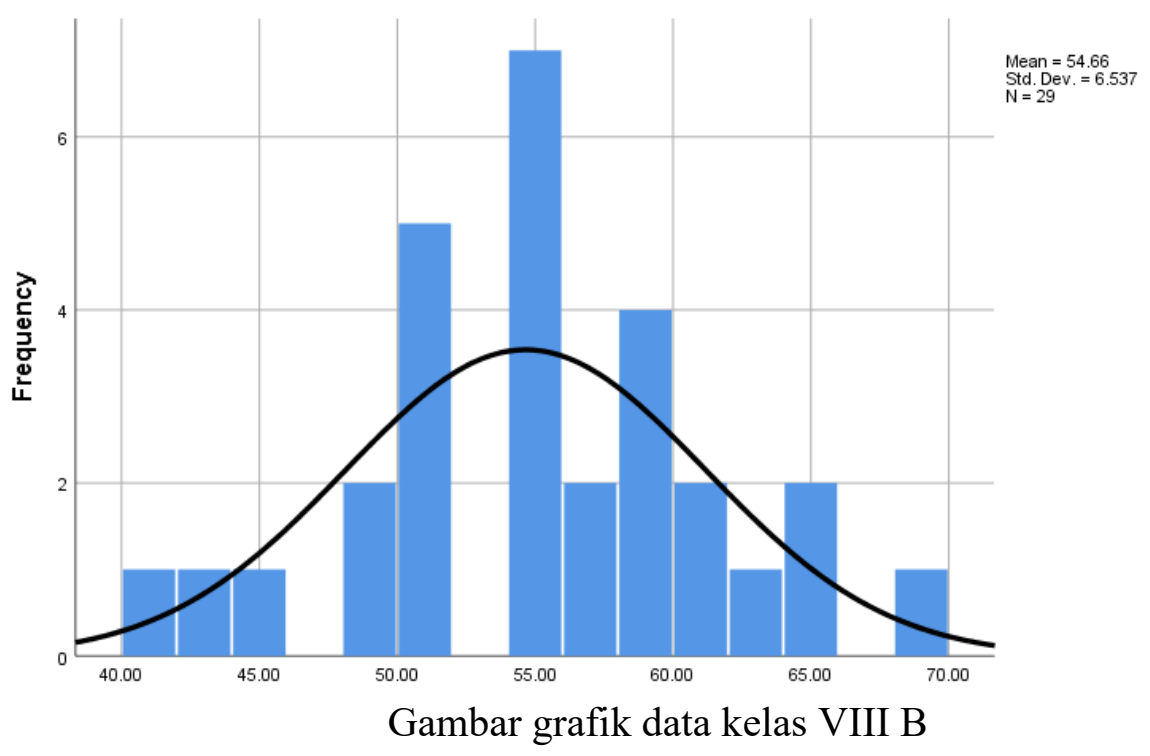

Untuk data observasi pada kelas VIII B, dengan menggunakan metode deskriptif statistik, data yang telah diperoleh kemudian diolah menggunakan SPSS untuk mendapatkan nilai rata-rata, median, modus, standar deviasi, nilai minimum dan maksimum. Diperoleh nilai terendah yaitu 41 dan tertinggi 68 dari total siswa 29 orang. Untuk nilai rata-rata sebesar 54.65, nilai tengah (median) sebesar 55, nilai yang paling banyak diperoleh yakni 50, dan untuk standar deviasi atau tingkat keragaman data sebesar 6.53.

Dari data nilai yang diperoleh siswa di kelas VIII B, diantaranya nilai 41 diperoleh oleh 1 siswa dengan presentase $3.4 \%$, nilai 42 diperoleh oleh 1 siswa dengan presentase $3.4 \%$, nilai 45 diperoleh oleh 1 siswa dengan presentase $3.4 \%$, nilai 48 diperoleh oleh 1 siswa dengan presentase $3.4 \%$, nilai 49 diperoleh oleh 1 siswa dengan presentase $3.4 \%$, nilai 50 diperoleh oleh 4 siswa dengan presentase $13.8 \%$, nilai 51 diperoleh oleh 1 siswa dengan presentase $3.4 \%$, nilai 54 diperoleh oleh 4 siswa dengan presentase $13.8 \%$, nilai 55 diperoleh oleh 3 siswa dengan presentase $10.3 \%$, nilai 57 diperoleh oleh 2 siswa dengan presentase 6.9 $\%$, nilai 58 diperoleh oleh 3 siswa dengan presentase $10.3 \%$, nilai 59 diperoleh

178 BRILIANT: Jurnal Riset dan Konseptual Volume 4 Nomor 2, Mei 2019 
oleh 1 siswa dengan presentase $3.4 \%$, nilai 60 diperoleh oleh 1 siswa dengan presentase $3.4 \%$, nilai 61 diperoleh oleh 1 siswa dengan presentase $3.4 \%$, nilai 62 diperoleh oleh 1 siswa dengan presentase $3.4 \%$, nilai 65 diperoleh oleh 2 siswa dengan presentase $6.9 \%$, dan nilai 68 diperoleh oleh 1 siswa dengan presentase $3.4 \%$.

Untuk rentang klasifikasi lembar angket " Karakter Rasa Ingin Tahu ", siswa pada kelas VIII A SMP Negeri 08 Muaro Jambi, sebagai berikut:

1. Rentang $25-43,75$ dalam kategori tidak baik

2. Rentang 43,76-62,5 dalam kategori cukup

3. Rentang $62,6-81,25$ dalam kategori baik

4. Rentang 81,26 - 100 dalam kategori sangat baik

Pengambilan data dilakukan pada kelas VIII A dan VIII B di SMP N 08 Muaro Jambi, maka dilakukanlah uji homogenitas menggunakan uji statitstik Levene dengan signifikansi $>0.05$. Dilihat dari hasil uji homogenitas yang telah dilakukan dengan nilai signifikansi sebesar $0.628>0.05$ maka semua populasi kelas VIII mempunyai varian yang sama.

Dan juga dilakukan uji asusmsi dasar, yakni uji Normalitas pada data penelitian yang didapat. Uji normalitas menggunakan uji Kolmogorov-Smirnov karena sampel penelitian berjumlah $>20$ orang. Pengambilan keputusan uji normalitas, yaitu apabila signifikansi $>0.05$ maka data tersebut terdistribusi normal. Dilihat dari hasil uji yang dilakukan, dengan signifikansi kelas VIII A dan VIII B, $0.200>0.05$ maka dapat disimpulakan data penelitian yang didapat terdistribusi normal.

\section{PEMBAHASAN}

Dalam proses belajar mengajar di kelas, sikap ataupun perilaku siswa berpengaruh besar dalam pencapaian hasil belajar. According Iaghatdar, et al. (2011), facts show, attitude students are one of the key factors in learning science. Dapat didefinisikan bahwa, dalam kenyataannya sikap siswa merupakan salah satu faktor kunci dalam belajar sains (IPA). Sikap sendiri merupakan wujud ekspresi atau tanggapan siswa terhadap objek pembelajaran. Sikap tersebut bisa berupa ungkapan menerima atau menolak objek tersebut. Pengukuran sikap dilakukan untuk melihat kemampuan individu terhadap suatu objek.

Data hasil observasi yang diperoleh, kemudian data tersebut telah dilakukan pengujian, yakni berupa uji normalitas dan uji homogenitas. Hasil uji tersebut menyebutkan bahwa data observasi berstatus normal dan homogen.

Karakter rasa ingin tahu peserta terhadap pelajaran, khususnya pelajaran fisika tergolong baik. Menurut Kemendiknas (2010: 10) dalam Yuritantri (2013), karakter rasa ingin tahu sendiri merupakan sikap dan tindakan yang selalu berupaya untuk mengetahui lebih mendalam dan meluas dari sesuatu yang dipelajarinya, dilihat, dan didengar.

Diperoleh nilai rata-rata di kelas VIII A dan VIII B, yaitu masing-masing 55.17 dan 54.65, dan pada rentang klasifikasi untuk 43.76 - 62.50 tergolong cukup, maka data observasi tersebut tergolong cukup . Maka tidak sepenuhnya benar untuk faktor penyebab pemahaman siswa terhadap mata pelajaran IPA fisika rendah, dikarenakan kurangnya karakter atau sikap rasa ingin tahu siswa terhadap pelajaran. Hasil penelitian ini juga relevan dengan hasil penelitian yang dilakukan oleh Lilanamami Arya Yuritantri yang berjudul " Pembelajaran dengan 
Metode Guided Inquiry ", bahwa pembelajaran dengan metode guided inquiry dapat mengembangkan rasa ingin tahu dan keterampilan komunikasi siswa.

\section{KESIMPULAN}

Karakter atau sikap seorang siswa akan sangat berpengaruh terhadap keberhasilan dan pencapaian dalam proses pembelajarannya. Termasuklah jika sikap rasa ingin tahu yang tinggi dimiliki oleh seorang siswa maka akan meningkatkan aktivitas belajarnya terhadap sebuah mata pelajaran. Dalam meningkatkan rasa ingin tahu siswa tersebut, maka juga sangat perlu dilakukan tindakan oleh pendidik yakni berupa dorongan. Baik itu dari segi strategi pembelajaran, metode pembelajaran, penggunaan media pembelajaran yang digunakan dalam proses kegiatan belajar mengajar di kelas, maupun tindakan yang dapat memotivasi siswa tersebut agar lebih bersemangat dan fokus pada pelajaran mereka.

\section{SARAN}

Agar karakter atau sikap rasa ingin tahu siswa lebih tinggi dan detail, maka pendidik tentu saja dapat melakukan sebuah metode pembelajaran yang lebih menarik perhatian siswa. Suatu proses pembelajaran yang dinilai efektif, yakni dimana saat proses pembelajaran berlangsung, perhatian siswa akan tertuju ke pelajaran.

\section{DAFTAR RUJUKAN}

Agung, I. Gusti Ngurah. 2000. Statistika: Analisis Data Kategorik. Materikuliah S2 Kependudukan dan Ketenagakerjaan dan S2/S3 FEUI (Naskah belum diterbitkan).

Agung, I. Gusti Ngurah. 2000. Analisis Statistik Sederhana untuk Pengambilan Keputusan. Jurnal Populasi. 11 (2): 1-2.

Ajeng, R. S., Hidayat, A., dan Yuliati, L. 2019. Kemampuan Multirepresentasi Siswa dalam Pembelajaran aPBL (Authentic Problem Based Learning) pada Materi Elastisitas dan Getaran. BRILIANT: Jurnal Riset dan Konseptual. 4 (1): 1.

Astalini, dkk. 2018. Sikap terhadap Mata Pelajaran IPA di SMP se- Kabupaten Muaro Jambi. Jurnal Lentera Pendidikan. 21 (2): 2.

Astalini, dkk. 2019. Identifikasi Sikap Peserta Didik terhadap Mata Pelajaran Fisika di Sekolah Menengah Atas Negeri 5 Kota Jambi. Jurnal Pendidikan Fisika. 8 (1): 2.

Djamarah, Syaiful., B. 2013. Strategi Belajar Mengajar. Jakarta: Rineka Cipta.

Erhasnyah. 2018. Urgensi Penerapan Pembelajaran berbasis Minat Siswa SMP. BRILIANT: Jurnal Riset dan Konseptual. 3 (4): 1. 
Fatonah, S. and Prasetyo, Z.K., 2014. Pembelajaran sains. Yogyakarta: Penerbit Ombak.

Kurniawan, D., A., dkk. 2018. Implikasi Sosial, Penyelidikan Ilmiah, dan Kesenangan Belajar Siswa pada Mata Pelajaran Fisika. Jurnal Pendidikan Indonesia. ISSN 0215-9643.

Kurniawan, D., A., dkk. 2018. Evaluasi Sikap Siswa SMP terhadap IPA di Kabupaten Muaro Jambi. Jurnal Ilmiah DIDAKTIKA. 19 (1): 2.

Liaghatdar, M., J. et al. 2011. A Validity Study of Attitudes toward Sciences Scale among Iranian Secondary School Students. International Education Studies. 4 (4): 1.

Nurhayati, I. 2018. Peningkatan Penguasaan Vocabulary Teks Deskriptif melalui Pendekatan Scientific dengan Model Guide Inquiry pada Siswa SMPN 1 Bekasi. BRILIANT: Jurnal Riset dan Konseptual. 3 (1): 4.

Suradi. 2017. Pembentukan Karakter Siswa melalui Penerapan Disiplin Tata Tertib Sekolah. BRILIANT: Jurnal Riset dan Konseptual. 2 (4): 3.

Yuritantri, L., A. 2013. Pembelajaran dengan Metode Guide Inquiry untuk Mengembangkan Rasa Ingin Tahu dan Keterampilan Komunikasi Siswa. Skripsi. Tidak diterbitkan. Fakultas Matematika dan Ilmu Pengetahuan Alam. Universitas Negeri Semarang: Semarang. 